Application of Final Income Tax (PPh) to Micro, Small, and Medium Enterprises (MSMEs) based on PP No. 23 of 2018 in the Work Area of the Depok Pratama Tax Service Office

\title{
Penerapan Pajak Penghasilan (PPh) Final terhadap Usaha Mikro Kecil dan Menengah (UMKM) berdasarkan PP No 23 Tahun 2018 pada Wilayah Kerja Kantor Pelayanan Pajak Pratama Depok
}

\begin{tabular}{l}
\hline Author \\
\hline Deddy Dariansyah \\
Universitas Indraprasta PGRI \\
Jakarta Timur \\
deddjazz@gmail.com
\end{tabular}

\section{Duconomics Sci-meet}

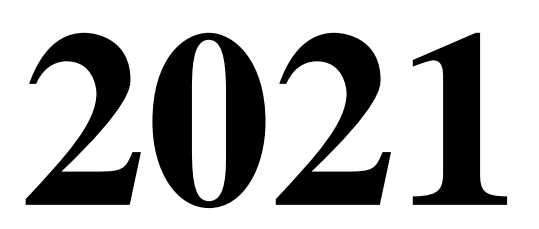

VOLUME 1 JULI

Page

15-19

DOI

10.37010/duconomics.v1.5347

\begin{abstract}
With the issuance of Government Regulation (PP) Number 23 of 2018 concerning Final Taxes which are specifically applied to small and medium businesses and certain businesses, which have a gross income of IDR 4.8 billion in one year. The purpose of this study is the author wants to examine whether the application of Final Income

Tax $(P P h)$ with a tariff of $0.5 \%$ for Micro, Small and Medium

Enterprises in Depok City is in accordance with Government

Regulation No. 23 of 2018. The method used in this study is to analyze reports MSME finances as well as the application of the gross Final Income Tax on income for certain businesses in 2020. Based on financial reports from food and beverage distributors in 2020 from May to June there was an increase in income to coincide with the fasting month of Ramadan, after the end of July the income

decreased again with the end of Eid al-Fitr, after analyzing and calculating based on financial reports, the income did not exceed Rp4,800,000,000 in one year. Taxpayers can get the final Income Tax rate on certain income category circulation
\end{abstract}

Keywords

government regulation, tax final, small medium, entreprise

Abstrak

Dengan dikeluarkannya Peraturan Pemerintah (PP) Nomor 23 Tahun 2018 tentang Pajak Final yang khusus diberlakukan bagi pelaku usaha kecil menengah dan usaha tertentu, yang memiliki penghasilan bruto $\mathrm{Rp} \mathrm{4,8} \mathrm{miliar} \mathrm{dalam} \mathrm{satu} \mathrm{tahun.} \mathrm{tujuan} \mathrm{dari} \mathrm{penelitian} \mathrm{ini} \mathrm{adalah}$ penulis ingin meneliti apakah penerapan Pajak Penghasilan (PPH) Final dengan tarif 0,5\% terhadap usaha Mikro Kecil dan Menengah pada Kota Depok sudah sesuai dengan Peraturan Pemerintah No 23 tahun 2018. Metode yang digunakan penelitian ini secara kualitatif dengan observasi dan wawancara dengan menganalisis laporan keuangan distributor makanan dan minuman atas Pajak Penghasilan Final bruto dengan tarif $0.5 \%$ pada tahun 2020 , telah sesuai dengan Peraturan Pemerintah No 23 tahun 2018 mengenakan tarif PPH Final

$0,5 \%$ setiap bulannya. Pada bulan Mei sampai dengan bulan Juni adanya kenaikan pendapatan bertepatan dengan bulan puasa Ramadan, setelah akhir bulan Juli pendapatan menurun lagi dengan berakhirnya hari raya Idu Fitri, setelah dilakukan analisa dan perhitungan berdasarkan laporan keuangan maka pendapatannya tidak melebihi Rp4.800.000.000 dalam satu tahun. Wajib Pajak bisa mendapatkan tarif Pajak Penghasilan final atas penghasilan kategori peredaran tertentu.

Kata kunci 


\section{PENDAHULUAN}

Berdasarkan laporan Kementerian Keuangan untuk Anggaran Pendapatan Belanja Negara (APBN) 2020, dari pemerintah menetapkan target penerimaan Pajak non-PPh Migas adalah Rp. 1.642.6 trilyun pemerintah mengusulkan rasio penerimaan Pajak (Tax Ratio) dalam Rancangan Anggaran Pendapatan dan Belanja Negara Perubahan (APBN) 2016 sebesar 13\% dari Produk Domestik Bruto (PDB). Dengan semakin meningkatnya target penerimaan negara dari sektor pajak pada struktur APBN dari tahun ke tahun, yang besarnya rasio penerimaan sektor pajak terhadap total penerimaan dalam negeri berkisar $78 \%$. untuk di tahun 2020 ini saja, total target penerimaan sektor pajak pada Anggaran Pendapatan Belanja Negara (APBN) Berikut ini Tabel Target Penerimaan Pajak selama 5 tahun dari Tahun 2016 sampai dengan 2020 dari Direktorat Jendral Pajak berdasarkan APBN adalah sebagai berikut:

\section{Tabel 1. Target Penerimaan Pajak 2016 sampai dengan 2020}

\begin{tabular}{ccc}
\hline No & Tahun Penerimaan Pajak & Jumlah Target Penerimaan \\
\hline 1 & 2016 & Rp1.355,3 triliun \\
2 & 2017 & Rp1540,2. triliun \\
3 & 2018 & Rp1.542,7 triliun \\
4 & 2019 & Rp1.577,6 triliun \\
5 & 2020 & Rp1.642,6 triliun \\
\hline
\end{tabular}

Sumber: Direktorat Jendral Pajak(2020)

Dari tabel di atas terlihat sangat jelas bahwa setiap tahunnya target penerimaan meningkat jumlah nya, berdasarkan Anggaran Pendapatan Belanja Negara (APBN). Hal ini diperlukan langkah-langkah strategis dan tepat oleh Direktorat Jendral Pajak sebagai institusi pengumpul penerimaan negara di Indonesia, agar rencana penerimaan pajak dapat tercapai, dari Pihak Direktorat Jendral Pajak menjalankan Program Ekstensifikasi dan Intensikasi, salah satu Program Ekstensifikasi di antaranya melalui pemungutan Pajak Penghasilan Final terhadap usaha Mikro Kecil dan Menengah berdasarkan Peraturan Pemerintah No 23 Tahun 2018. Hal serupa

berdasarkan Data dari Kementerian Koperasi dan UMKM, pada tahun 2020 berjumlah pengusaha UMKM berjumlah 64.194.057 sebagai berikut:

\begin{tabular}{|c|c|c|}
\hline No & Skala Usaha & Jumlah Usaha \\
\hline 1 & Usaha Mikro & 63.350 .222 \\
\hline 2 & Usaha Kecil & 783.132 \\
\hline 3 & Usaha Menengah & 60.172 \\
\hline & Jumlah & 64.194 .057 \\
\hline
\end{tabular}

Dari jumlah tersebut masih banyak ditemukannya pengusaha UMKM belum memahami dalam hal perhitungan, penyetoran, pelaporan Pajak serta pengisian SPT pajak. Dalam upaya meningkatkan pengetahuan dan pemahaman bagi pengusaha UMKM tentang perpajakan, kegiatan penyuluhan dan sosialisasi pajak memegang peran yang sangat penting dalam upaya mengedukasikan pemahaman perpajakan kepada masyarakat dan pengusaha UMKM), serta menjadikan paham, patuh dan sadar dalam memenuhi kewajiban perpajakannya. Kepatuhan masyarakat (Wajib Pajak) salah satu diantaranya pengusaha UMKM dalam memenuhi kewajiban membayar Pajak. Upaya dalam meningkatkan pengetahuan dan pemahaman masyarakat tentang kewajiban Perpajakan, kegiatan Penyuluhan dan Sosialisasi perlu terus dilakukan dengan cara yang lebih terencana, terarah dan terukur. Setelah melalui proses kajian dan pembahasan serta sosialisasi yang panjang selama dua tahun, baik dalam instansi 
pemerintah terkait maupun masukan dari berbagai pihak, akhirnya pemerintah mengeluarkan kebijakan Peraturan Pemerintah (PP) No 23 Tahun 2018. Pajak Final yang khusus berlaku bagi usaha pelaku usaha kecil menengah dan usaha tertentu. Peraturan pajak ini mengatur tentang perlakuan Pajak Penghasilan ( $\mathrm{PPh}$ ) yang memiliki peredaran bruto tertentu, pengertian peredaran Bruto tertentu adalah penghasilan yang diterima atau diperoleh Wajib Pajak dari usaha yang jumlah sampai dengan Rp4.800.000.000 dalam satu tahun cukup dikenakan pajak 0,5\% setiap bulannya. Secara tersirat kebijakan ini merupakan perlakuan Pajak Penghasilan $(\mathrm{PPh})$ final atas Usaha Mikro Kecil dan Menengah (UMKM) dihubungkan dengan pengertian, kondisi dan kriteria sebagaimana ditetapkan dalam Undang Undang No 20 tahun 2008 tentang Usaha Mikro Kecil dan Menengah. Dalam praktiknya, bila dilakukan penelitian secara langsung kepada subjek pajak, bahwa melaksanakan kewajiban pajak dengan kondisi Peraturan Perpajakan saat ini yang sederhana, mudah dilaksanakan dengan tarif yang sangat rendah merupakan salah satu yang diinginkan oleh masyarakat. Kondisi tersebut tidak terkecuali bagi kalangan pelaku usaha yang tergolong dalam Usaha Mikro Kecil dan Menengah dengan berbagai keterbatasan yang ada ditengah kegiatan usaha yang dilakukan saat ini, dengan kondisi ini hasil yang diharapkan dapat diperoleh yaitu berupa keuntungan yang telah diharapkan, sehingga dapat menjaga dan mendorong kelangsungan usaha mikro kecil dan menengah yang terus berlanjut, atas dasar pemikiran tersebut penulis tertarik untuk meneliti Penerapan Pajak Penghasilan (PPh) Final terhadap Usaha Mikro Kecil dan Menengah(UMKM) Pada wilayah kerja Kantor Pelayanan Pajak Kecamatan Kramat Jati.

\section{METODE}

Metode yang digunakan Penelitian ini secara kualitatif dengan observasi dan wawancara dengan menganalisa laporan keuangan UMKM serta penerapan atas Pajak Penghasilan Final bruto terhadap penghasilan peredaran usaha tertentu bagi Wajib Pajaak Distributor makanan dan minuman pada tahun 2020, sesuai dengan Peraturan Pemerintah No 23 tahun 2018 mengenakan tarif PPh Final 0,5\% setiap bulannya atas usaha Wajib pajak terhadap penghasilan peredaran usaha tertentu. Apabila seandainya ditahun 2016 Wajib Pajak penghasilan bruto nya melebihi Rp4,8 milar pertahun maka tidak lagi masuk kategori penghasilan kategori tertentu, melainkan penghitungan pajak sudah secara umum dan tarif pajak penghasilan umum sesuai dengan UU PPh No 36 Tahun 2008.

\section{HASIL DAN PEMBAHASAN}

\section{Hasil}

\section{Dasar Pengenaan Pajak}

Sebagai dasar pengenaan pajak dalam menghitung pajak yang terutang, secara umum formulanya adalah:

Pajak terutang $=$ Tarif 0,5\% $\mathrm{x}$ Dasar Pengenaan Pajak

Berdasarkan perhitungan dan analisa Laporan Keuangan Distributor makanan dan minuman selama bulan Januari sampai dengan Desember 2020 mendapatkan penghasilan bruto adalah sebagai berikut:

$$
\begin{array}{ll}
\text { Januari Rp 154.740.100 x 0,5\% } & =R p 773.700 \\
\text { Februari Rp 145.250.050 x 0,5\% } & =R p 726.250
\end{array}
$$


Maret Rp 149.340.010 x 0,5\%

April Rp $153.870 .035 \times 0,5 \%$

Mei Rp 156.760.020 x 0,5\%

Juni Rp 163.220.040 x $1 \%$

Juli Rp 160.250.030 x 0,5\%

Agustus Rp 152.740.010 x 0,5\%

September Rp 150.250.510 x 0,5\%

Oktober Rp 149.340.060 x 0,5\%

November Rp 143.870.070 x 0,5\%

Desember Rp148.534.700 x 0,5\%
$=\operatorname{Rp} 746.700$

$=\operatorname{Rp} 769.350$

$=\mathbf{R p} \mathbf{7 8 3 . 8 0 0}$

$=$ Rp 816.100

$=\mathbf{R p} 801.250$

$=\operatorname{Rp} 763.700$

$=\operatorname{Rp} 751.252$

$=\operatorname{Rp} 746.700$

$=\operatorname{Rp} 719.350$

$=\operatorname{Rp} 742.673$

\section{Pembahasan}

Berdasarkan laporan keuangan dari Distributor makanan dan minuman pada tahun 2020, pada bulan Mei sampai dengan bulan Juni adanya kenaikan pendapatan betepatan dengan bulan puasa ramadhan, setelah akhir bulan Juli pendapatan menurun lagi dengan berakhirnya hari raya Idu Fitri, Dengan adanya perhitungan diatas tadi maka Pengusaha Distributor makan dan minuman pada wilayah kerja Kantor Pelayanan Pajak Depok sudah menerapkan sesuai dengan Peraturan Pemerintah No 23 Tahun 2018 besarnya tarif Pajak Penghasilan (PPh ) atas penghasilan kategori peredaran bruto tertentu yaitu $0,5 \%$ ini diberlakukan hanya atas penghasilan usaha yang diterima atau diperoleh Wajib Pajak dengan kategori peredaran bruto tertentu. Dengan mengacu kepada kriteria besaran omset (hasil penjualan) maka bagi Usaha Mikro Kecil dan Menengah seluruhnya termasuk sebagai Wajib Pajak dengan kategori Peredaran Bruto Tertentu. Sehubungan dengan jumlah peredaran bruto tertentu tidak melebihi Rp4.800.000.000 dalam satu tahun. Wajib Pajak bisa mendapatkan tarif Pajak Penghasilan final atas penghasilan kategori peredaran tertentu, dengan mengajukan permohonan surat keterangan bebas (SKB) atas pemotongan / pemungutan pajaknya dari Kantor Pelayanan Pajak terdaftar sebagai Wajib Pajak Pengusaha Kecil. Surat permohonan keterangan bebas (SKB) PPh No 23 tahun 2018 digunakan oleh Wajib Pajak yang memiliki peredaran bruto tertentu yaitu wajib pajak yang dikenakan pajak penghasilan bersifat final, yang diterima atau diperoleh Wajib Pajak yang memiliki peredaran tertentu agar tidak dipotong atau dipungut $\mathrm{PPh}$ pasal 21/22/23 oleh pemungut /pemotong pajak apabila terjadi penjualan / pemotong pajak apabila terjadi transaksi penjualan barang / penyerahan jasa. Permohonan pembebasan dari pemotongan dan atau pemungutan pajak penghasilan dapat diajukan secara tertulis kepada Kepala Kantor Pelayanan Pajak tempat Wajib Pajak menyampaikan kewajiban Surat Pemberitahuan Tahunan dengan syarat:

1. Telah menyampaikan Surat Pemberitahuan Tahunan Pajak penghasilan Tahun pajak sebelum tahun diajukan permohonan, untuk Wajib Pajak yang telah terdaftar pada tahun pajak sebelum tahun pajak diajukan surat keterangan bebas (SKB).

2. Menyerahkan surat pernyataan yang ditanda tangani Wajib Pajak atau kuasa khusus Wajib Pajak yang menyatakan bahwa peredaran bruto usaha yang diterima atau diperoleh termasuk dalam kriteria untuk dikenai pajak penghasilan bersifat final disertai lampiran jumlah peredaran bruto setiap bualan sampai dengan bualn sebelum diajukan nya keterangan bebas, untuk wajib pajak yang terdaftar pada tahun pajak yang sama dengan Tahun Pajak saat diajukan

3. Ditanda tangani oleh Wajib Pajak, dalam hal permohonan ditanda tangani oleh bukan wajib pajak harus dilampiri dengan surat kuasa khusus.

Apabila Wajib Pajak UMKM telah mendapatkan Surat Keterangan Bebas (SKB) dari Kantor Pelayanan Pajak, maka bisa mendapatkan fasilitas pengenaaan pajak sesuai dengan peraturan pemerintah No 23 Tahun 2018 


\section{PENUTUP}

dari data tersebut diatas merupakan sangat bagus untuk potensi penerimaan pajak dari Direktorat Jendral Pajak, khususnya Kantor Pelayanan Pajak Pratama Kramat jati agar menjalankan Program Ekstensifikasi Pajak, sangat bermanfaat untuk menjaring Wajib Pajak UMKM baru sebagai penerimaan pajak pada Kantor Pelayanan Pajak Kramat Jati. Berbagai macam cara menjalankan program Ekstensifikasi Pajak dalam menjaring Wajib Pajak UMKM yang ada di wilayah Kantor Pelayanan Pajak Kramat Jati antara lain:

1. Mapping Survey terhadap pelaku usaha UMKM di wilayah Kota Depok

2. Melaksanakan sosialisasi Peraturan Pemerintah No 23 Tahun 2018 dengan peredaran usaha sampai Rp4.800.000.000 dikenakan tarif 0,5 \% terhadap pelaku usaha UMKM dengan mendatangi di tempat usaha UMKM, Pasar tradisional, Mall, acara Bazaar, Kantor Kelurahan dan Kantor Kecamatan diseluruh wilayah Depok

3. Mengadakan program jemput bola dari Kantor Pelayanan Pajak Depok dengan mendatangani pelaku usaha UMKM dalam memberikan Nomor Pokok Wajib Pajak (NPWP) serta menerima laporan Surat Pemberitahuan Tahun (SPT) Wajib Pajak UMKM.

\section{DAFTAR PUSTAKA}

Kantor Pelayanan Pajak Pratama. (2019). Laporan Data Penerimaan Pajak dan Wajib Pajak. Depok

Kementerian Keuangan. (2019). Laporan Anggaran Pendapatan Belanja Negara (APBN).

Kementerian Koperasi dan UMKM RI. (2019). Laporan Data Usaha Mikro Kecil dan Menengah.

Peraturan Menteri Keuangan (PMK) Nomor: 197/PMK.03/2013 tentang pengusaha kecil pajak. Peraturan Menteri Keuangan No 132/PMK/2006, Struktur Organisasi Kantor Pelayanan Pajak Pratama

Peraturan Pemerintah No 46 Tahun 2013, tentang Pajak Penghasilan atas Penghasilan dari usaha yang diterima atau diperoleh Wajib Pajak yang memiliki peredaran tertentu.

Soemitro, R. (1992). Dasar Dasar Hukum Pajak. Bandung: Penerbit Eresco.

Undang Undang Nomor 20 Tahun 2008 tentang Usaha Mikro Kecil dan Menengah 